\title{
ДИДАКТИЧНІ МОДЕЛІ ФОРМУВАННЯ БАГАТОМОВНОЇ ОСОБИСТОСТІ: МОДЕЛЬ ФАКТОРІВ І ФУНКЦІОНАЛЬНА МОДЕЛЬ
}

\author{
ЮЛІЯ ТАЛАЛАЙ \\ Дрогобицький державний педагогічний університет імені Івана Франка, \\ Дрогобич - Україна \\ jutal@ukr.net; ORCID: 0000-0003-3134-2030
}

\section{DYDAKTYCZNE MODELE KSZTAŁTOWANIA OSOBOWOŚCI WIELOJĘZYCZNEJ: MODEL CZYNNIKÓW I MODEL FUNKCJONALNY}

\author{
JULIA TAŁAŁAJ \\ Państwowy Uniwersytet Pedagogiczny imienia Iwana Franki w Drohobyczu, \\ Drohobycz - Ukraina
}

STRESZCZENIE. W artykule scharakteryzowano dydaktyczne modele kształtowania wielojęzycznej osobowości ucznia w procesie uczenia się języka obcego, takie jak: model czynników oraz model funkcjonalny. Określono istotę modelu czynników, polegającą na uwzględnieniu systemu faktorów zewnętrznych i wewnętrznych, odgrywających ważną rolę w procesie uczenia się języka obcego. Cechami charakterystycznymi modelu czynników jest wielostopniowa struktura i porządek chronologiczny systematyzacji modelu, które polegają na wpływie pierwszego języka obcego podczas posługiwania się przez uczniów drugim czy trzecim językiem obcym.

Słowa kluczowe: model dydaktyczny, osobowość wielojęzyczna, model czynników, model funkcjonalny, język obcy, uczenie się.

\section{DIDACTIC MODELS OF MULTILINGUAL PERSONALITY FORMATION: FACTOR AND FUNCTIONAL MODELS

\author{
YULIYA TALALAY \\ Drohobych Ivan Franko State Pedagogical University, Drohobych — Ukraine
}

\begin{abstract}
The article focuses on the analysis of the didactic models of the multilingual personality formation. The factor model and the functional model of the multilingual personality formation have been characterized. The essence of the factor model consists in the system of external and internal factors that play an important role in the process of learning foreign languages. The main characteristics of the factor model are: a multistage structure and the chronological order of the different factors systematization. The essence of the functional model has been singled out. This essence consists in the influence of the first foreign language on the second, third foreign languages during the process of speaking.

Key words: didactic model, multilingual personality, factor model, functional model, foreign languages, learning.

$\Pi$ осилення євроінтеграційних процесів на зламі XIX-XX століть, визнання індивідуальної й соціальної багатомовності “ключем до європейської інтеграції” - це найсуттєвіші передумови формування європейської ідентичності, досягнення взаєморозуміння між країнами-членами СС.

У березні 2002 р. на засіданні країн-членів Свропейського Союзу в Барселоні глави держав і урядів уклали програму “СС Барселона - Ціль L1 + L2”,
\end{abstract}


зазначивши таке: „Діти, починаючи з раннього віку, повинні вивчати принаймні дві іноземні мови" (переклад автор. - Ю. Т.) ${ }^{1}$. Англійська мова займає домінуюче положення в шкільній програмі вивчення іноземних мов в Австрії та в реалізації цілей (IM1 + IM2) у процесі обов'язкової освіти. Згідно з положеннями Програми “СC Барселона - Ціль L1 + L2", окрім збереження чинних освітніх навчальних програм, слід також: а) розвивати мовну різноманітність; б) розширити вивчення другої, третьої іноземних мов у старших школах країн-членів СС.

В установчому документі ЮНЕСКО “Освіта в багатомовному світі” подано строгу рекомендацію щодо застосування таких принципів багатомовної освіти:

а) навчання рідною мовою - один із засобів підвищення якості освіти;

б) двомовне (багатомовне) навчання на усіх освітніх ланках сприяє забезпеченню соціальної рівності;

в) мова - найважливіший компонент міжкультурної освіти.

За визначенням ЮНЕСКО, мови є одним з найважливіших елементів культури. Мова - найважливіший чинник ідентифікації кожної людини, а мовне різноманіття — гарантія культурного розмаїття². У 2003-2004 pp. Сврокомісія спільно з Радою Європи прийняла й рекомендувала "План дій з вивчення мов і збереження мовного різноманіття". У документі передбачалися такі дії з вивчення мов:

а) навчання мов усіх громадян незалежно від віку;

б) підвищення якості навчання: створення в школах сприятливого середовища для навчання мов;

в) підготовка вчителів для багатомовної освіти ${ }^{3}$.

Для втілення Плану дій з вивчення мов було запроваджено Європейське мовне портфоліо та систему Загальноєвропейських мовних компетентностей (CEFR), що становить систему рівнів володіння нерідною мовою. Система створена фахівцями Ради Свропи в рамках проекту “Вивчення мов для європейського громадянства" (Language Learning for European Citizenship) 4 Стратегічні напрями розвитку багатомовної освіти в СС передбачали:

а) навчання мов упродовж життя;

б) удосконалення процесу викладання мов, підвищення його ефективності;

в) створення сприятливих умов для опанування мовами в соціумі 5 .

Пріоритети мовної освітньої політики в країнах Західної та Центральної Європи зумовили якісно нові вимоги до теорії й практики іншомовної освіти та актуалізували процес переосмислення засадничих положень традиційної лінгводидактики, що передбачала певною мірою фрагментоване навчання мов, проголошувала впорядковане й відокремлене співіснування ключовим принципом оволодіння мовами, а поєднання й перенесення знань і вмінь 3 різних мов - джерелом інтерференції. Результати новітніх наукових студій у галузі психофізіології, психолінгвістики, когнітивної психології й лінгвістики переконливо довели, що вивчення декількох іноземних мов $є$ активним, творчим, індивідуальним процесом, спрямованим на формування єдиної, цілісної систе-

${ }^{1}$ Barcelona-Ziel, [in:] Electronic resourse: www.ec.europa.eu/education/languages/pdf/com/ 2008_0566_cs.pd. (22.02.2018).

${ }^{2}$ ЮНЕСКО, Всесторонняя приверженность языковому разнообразию и многоязычию. Международный год языков, 2007, [в:] Электронный ресурс: http://www.un.org/ru/events/iyl/brochure/unesco.shtml (22.02.2018).

${ }^{3}$ P. Andersen, Education and Training. Work program-challenges and results, Brussels 2008.

${ }^{4} \mathrm{~B}$. Busch, Trends and innovative practices in multilingual education in Europe: an overview, Brussels 2011, p. 541-549.

${ }^{5}$ Ibidem, p. 542. 
ми з усіх наявних у пам'яті лінгвістичних елементів, яка $з$ освоєнням кожної нової мови постійно розширюється й диференціюється.

Висновки цих досліджень були покладені в основу низки концепцій і моделей, у яких докладно аналізуються відмінності в процесах освоєння декількох іноземних мов, пояснюються механізми вивчення першої, другої іноземних мов та розкриваються способи формування багатомовної особистості.

Мета статті - схарактеризувати дидактичні моделі формування багатомовної особистості в процесі вивчення іноземної мови: модель факторів і функціональна модель.

Проблемою дослідження дидактичних моделей формування багатомовної особистості займались австрійські науковці Ф. Гердіна, У. Ссснер ${ }^{78}$, німецька дослідниця Б. Гуфайзен ${ }^{9}$ та британська лінгвістка В. Кук ${ }^{10}$. Широкої популярності у світовому науковому просторі набула модель факторів доктора філології, професора Дармштадського технічного університету Б. Гуфайзен. У межах цієї моделі автор презентує низку зовнішніх і внутрішніх факторів, що відіграють вирішальну роль у процесі освоєння мов залежно від послідовності їхнього вивчення, приділяючи водночас особливу увагу тим, що мають винятково важливе значення для раціональної організації процесу іншомовної освіти, спрямованої на формування плюрилінгвальної особистості. Характерними ознаками моделі факторів є багатоступенева структура й хронологічний порядок систематизації чинників вивчення мов.

Свої міркування щодо цієї проблеми вчена розпочинає з аналізу рушійних сил і передумов освоєння дитиною рідної мови, указуючи на два комплекси факторів, що впливають на цей процес, а саме: природні, нейрофізіологічні особливості й задатки до оволодіння мовленням та якість впливів безпосереднього мовного оточення. У процесі вивчення рідної мови дитина поступово освоює комплекс знань про мову, особливості ії функціонування й практичного використання, а також набуває цінного життєвого й навчального досвіду, які використовує як опору в процесі подальшого навчання. Як наслідок - під час вивчення першої іноземної мови спектр чинників суттєво зростає насамперед квантитативно, охоплюючи, окрім загальної природної здатності до освоєння мови та впливів зовнішнього середовища, ще три групи факторів, зокрема лінгвістичні (мовні й мовленнєві знання, уміння, навички), емоційні (мотивація, індивідуальні установки, переживання тощо) та когнітивні (мовна й метамовна свідомість, індивідуальний ментальний досвід, пізнавальний стиль тощо). Саме на цьому етапі, за переконаннями Б. Гуфайзен, закладається основа для формування плюрилінгвізму в особистості.

Процес вивчення третьої іноземної мови відповідно до моделі факторів Б. Гуфайзен характеризується не лише подальшим кількісним зростанням відповідних чинників, а й суттєвим ускладненням їхньої взаємодії, адже дитина значно розширила спектр своїх лінгвістичних знань, комунікативних умінь і на-

${ }^{6}$ P. A. Herdina, Dynamic Model of Multilingualism: Perspectives of Change in Psycholinguistic, Cleveldon 2002, p. 89-91.

${ }^{7}$ P. A. Herdina, U. Jesner, Multilingual matters, [in:] Electronic resourse: http://www.multilingual-matters.com/display.asp?isb=9781783095292 (11.01.2018).

${ }^{8}$ U. Jessner, Bilingualismus und Drittspracherwerb: Dynamische Aspekte des Multilingualismus auf individueller Ebene, Tübingen 1998, s. 149-158.

${ }^{9}$ B. Hufeisen, Gesamtsprachencurriculum: Einflussfaktoren und Bedingungsgefüge, Tübingen 2005, s. 9-18.

${ }^{10}$ V. Cook, Writing papers, [in:] Electronic resourse: http://www.viviancook.uk/Writings/Papers/ MCentry.htm (22.02.2018). 
вичок, набула певного досвіду в освоєнні іноземної мови, оволоділа конкретними стратегіями її вивчення тощо. Відтак, крім усіх названих вище груп чинників, на цьому етапі формування багатомовної особистості дитини вирішальну роль, за твердженнями науковця, відіграють так звані специфічні іншомовні, до яких належать як конкретні лінгвістичні знання з іноземної мови, так й індивідуальний досвід іншомовної комунікації, а також відповідна навчально-стратегічна компетентність в оволодінні іншомовним мовленням.

Під час освоєння наступних іноземних мов комплекс факторів, що впливають на цей процес, як зазначає названий науковець, зростає більшою мірою в якісному, ніж у кількісному плані. Водночас вона наголошує, що освоєння учнем іноземних мов здійснюється під впливом специфічного лише для нього комплексу факторів, крім того, деякі з них можуть домінувати й мати більш сильний ефект у процесі оволодіння іноземними мовами, а дія інших може бути порівняно незначною.

Отже, модель факторів Б. Гуфайзен демонструє передусім більш суттєві відмінності між вивченням першої та другої іноземних мов, аніж між освоєнням другої та третьої іноземних мов, що відображаються в наявності в другому випадку відповідного навчально-пізнавального досвіду, володінні учнями комунікативними й навчальними стратегіями, необхідними для формування іншомовної компетентності. Головна ідея моделі факторів Б. Гуфайзен полягає в переконанні про можливість і доцільність конструктивного використання попередньо набутих лінгвістичних знань, комунікативних умінь та індивідуального навчально-пізнавального досвіду учня в процесі освоєння нових мов, що, за твердженнями автора, $\epsilon$ правильним шляхом, який веде до становлення плюрилінгвальної особистості. Завдяки цьому досвіду вивчення першої іноземної мови, яким, за переконаннями дослідниці, не можна нехтувати, навчання другої та третьої іноземних мов варто починати з більш високого рівня (у старшій школі), ніж навчання першої іноземної мови, що мотивується ускладненням змісту навчання і спрямоване на очікування кращих і швидших результатів.

Виходячи із засадничих положень моделі факторів, Б. Гуфайзен стала ініціатором розробки для системи шкільної освіти так званого наскрізного плану (Gesamtsprachencurriculum) $)^{11}$, мета якого передбачає спрощення вивчення та навчання мов, сприяння шкільній багатомовності й системному формуванню мовної свідомості й мовної уваги на міждисциплінарному рівні; використання синергетичного ефекту від вивчення кількох мов; системну інтеграцію індивідуальної й суспільної багатомовності в усі навчальні дисципліни тощо. Наскрізний план навчання мов не передбачає збільшення годин на жодну мову, але створює умови для їхнього більш ефективного викладання завдяки перерозподілу й узгодженню змісту навчання шкільних дисциплін мовного й немовного блоків.

В основу наскрізного плану навчання мов, як зазначає Б. Гуфайзен, має бути покладена виважена схема розвитку мовної компетенції насамперед з тих мов, які для учнів $є$ рідними або домінуючими. Надалі цей мовний досвід слугуватиме міцним фундаментом для засвоєння низки іноземних мов. Зокрема план передбачає вивчення трьох іноземних мов (першої іноземної мови - 3 другого класу, другої - 3 четвертого, третьої - 3 шостого) як у формі традиційної навчальної дисципліни, так і в межах білінгвального навчання. Наступний етап передбачає вивчення низки дисциплін, не пов'язаних безпосередньо $з$ формаль-

${ }^{11}$ B. Hufeisen, Gesamtsprachencurriculum: Einflussfaktoren und Bedingungsgefüge, Tübingen 2005, s. 9-18. 
ним вивченням мови, напр., пропонуються інтегровані курси, у межах яких різноманітні сфери суспільного життя й діяльності, скажімо, мистецтво, культура, політика, економіка, підлягають глибокому вивченню на основі аналізу оригінальних іншомовних текстів, документів, джерел. Зазначимо, що на сучасному етапі наскрізний план навчання мов 3 метою перевірки його ефективності в контексті національних систем шкільної освіти перебуває на стадії апробації в декількох європейських країнах (Німеччина, Естонія, Франція, Італія, Литва, Австрія, Чехія) і супроводжується підтримкою науковців та освітян.

Функціональна модель формування багатомовної особистості розроблена вченими Сарою Уїльямс і Берном Хаммарбергом у 1998 p. $^{12}$. Це психолінгвістична модель формування багатомовної особистості, що репрезентує розширення моделі породження мовлення, запропонованої американським ученим Уїльямом Левелтом ${ }^{13}$. У. Левелт розподіляє процес породження мовлення на три етапи:

а) концептуалізації, продуктом якого є довербальне повідомлення;

б) формулювання, продукт якого - граматичне й фонологічне кодування у взаємодії з лексиконом;

в) артикуляції, під час цього етапу фонетичний план (внутрішнє мовлення) перетворюється на зовнішнє.

С. Уїльямс і Б. Хаммарберг використали модель, запропоновану У. Левелтом, з метою з'ясування ролі різних мов, якими володіють учні, у процесі породження їхнього мовлення. Головна ідея цієї моделі полягає в тому, що під час говоріння другою чи третьою іноземними мовами перша іноземна мова домінує, використовується частіше ${ }^{14}$ й виконує функцію так званої зовнішньої підтримки ${ }^{15}$. На думку авторів цієї моделі, перша іноземна мова постійно активізується в процесі навчання другої іноземної мови, впливаючи на неї. Рідна мова домінує на прагматико-функціональному мовному рівні та впливає на процес вимови звуків першої та другої іноземних мов.

Отже, сутність моделі факторів полягає в урахуванні системи зовнішніх та внутрішніх чинників, що відіграють важливу роль у процесі навчання іноземної мови, тоді як функціональна модель ілюструє вплив першої іноземної мови на другу та третю іноземні мови.

Перспективу досліджень з актуалізованої проблематики вбачаємо в аналізі екологічної та контрастивно-лінгвістичної моделей формування багатомовної особистості учня в процесі навчання іноземної мови.

\section{Список використаної літератури}

ЮНЕСКО, Всесторонняя приверженность языковому разнообразию и многоязычию. Международный год языков, 2007, [в:] Электронный ресурс : http://www.un.org/ $\mathrm{ru} / \mathrm{events} / \mathrm{iyl} / \mathrm{brochure/.shtml} \mathrm{(22.02.2018).}$

${ }^{12} \mathrm{~S}$. Williams, Language switches in L 3 production: Implications for a polyglot speaking model, Oxford 1998, s. 295-333.

13 W. Levelt, Speaking: From Intention to Articulation. Massachusetts : Massachusetts Institute of Technology, [in:] Electronic resourse: http://ru.scribd.com/doc/131696239/15-A-LeveltSpeaking-1989 (20.01.2018).

${ }^{14} \mathrm{~S}$. Williams, Language switches in L 3 production: Implications for a polyglot speaking model, Oxford 1998, s. 295-333.

${ }^{15}$ B. Hammarberg, Roles of L 1 and L 2 in L 3 Production and Acquisition, Clevedon 2001, s. 21-41. 
Ю. Талалай

Andersen P., Education and Training. Work program-challenges and results, Brussels 2008.

Barcelona-Ziel, [in:] Electronic resourse: www.ec.europa.eu/education/languages/pdf/ com/2008_0566_cs.pd. (22.02.2018).

Busch B., Trends and innovative practices in multilingual education in Europe: an overview, Brussels 2011, p. 541-549.

Cook V., Writing papers, [in:] Electronic resourse: http://www.viviancook.uk/Writings/ Papers/MCentry.htm (22.02.2018). s. $21-41$.

Hammarberg B., Roles of L 1 and L 2 in L 3 Production and Acquisition, Clevedon 2001,

Herdina P. A., Jesner U., Multilingual matters, [in:] Electronic resourse : http://www. multilingual-matters.com/display.asp?isb=9781783095292 (11.01.2018).

Herdina P. A., Dynamic Model of Multilingualism: Perspectives of Change in Psycholinguistic, Cleveldon 2002, s. 89-91.

Hufeisen B., Gesamtsprachencurriculum: Einflussfaktoren und Bedingungsgefüge, Tübingen 2005, s. 9-18.

Jessner U., Bilingualismus und Drittspracherwerb : Dynamische Aspekte des Multilingualismus auf individueller Ebene, Tübingen 1998, s. 149-158.

Levelt W., Speaking: From Intention to Articulation. Massachusetts : Massachusetts Institute of Technology, [in:] Electronic resourse: http://ru.scribd.com/doc/131696239/15-ALevelt-Speaking-1989 (20.01.2018).

Williams S., Language switches in L 3 production: Implications for a polyglot speaking model, Oxford 1998, s. 295-333.

\section{Spysok vykorystanoi literatury [References]}

JUNESKO, Vsestoronnjaja priverzhennost jazykovomu raznoobraziju i mnogojazychiju. Mezhdunarodnyj god jazykov [Multi Favourism to Language Variety and Multiligualism], 2007, [v:] E’lektronnyj resurs: http://www.un.org/ru/events/iyl/brochure/.shtml (22.02.2018).

Andersen P., Education and Training. Work program-challenges and results, Brussels 2008.

Barcelona-Ziel, [in:] Electronic resourse : www.ec.europa.eu/education/languages/pdf/ com/2008_0566_cs.pd. (22.02.2018).

Busch B., Trends and innovative practices in multilingual education in Europe: an overview, Brussels 2011, p. 541-549.

Cook V., Writing papers, [in:] Electronic resourse: http://www.viviancook.uk/Writings/ Papers/MCentry.htm (22.02.2018).

Hammarberg B., Roles of L 1 and L 2 in L 3 Production and Acquisition, Clevedon 2001, s. $21-41$.

Herdina P. A., Jesner U., Multilingual matters, [in:] Electronic resourse: http://www. multilingual-matters.com/display.asp?isb=9781783095292 (11.01.2018).

Herdina P. A., Dynamic Model of Multilingualism: Perspectives of Change in Psycholinguistic, Cleveldon 2002, s. 89-91.

Hufeisen B., Gesamtsprachencurriculum: Einflussfaktoren und Bedingungsgefüge, Tübingen 2005, s. 9-18.

Jessner U., Bilingualismus und Drittspracherwerb : Dynamische Aspekte des Multilingualismus auf individueller Ebene, Tübingen 1998, s. 149-158.

Levelt W., Speaking: From Intention to Articulation. Massachusetts : Massachusetts Institute of Technology, [in:] Electronic resourse: http://ru.scribd.com/doc/131696239/15-ALevelt-Speaking-1989 (20.01.2018).

Williams S., Language switches in L 3 production: Implications for a polyglot speaking model, Oxford 1998, s. 295-333. 